\title{
Recordações da infância: as primeiras letras com a família Lutz
}

\author{
Depoimento de José de Barros Ramalho Ortigão Junior
}

A irmã mais velha de Adolpho Lutz, dona Maria Elisabeth Lutz, casou-se com o major Wilhelm Warnstorff, e com ele teve duas filhas, a Paula e a Gertrudes Lutz Warnstorff. O major devia ter um cargo na alta burocracia do império austríaco, e por razões políticas teve que vir embora. O major Warnstorff e dona Maria Elizabeth vieram de Viena para o Rio de Janeiro, e logo foram contratados como preceptores dos príncipes imperiais. A princesa d. Isabel morava no Palácio Guanabara, e eles foram residir naquele prédio ao lado, onde hoje é a escola Anne Frank, e que durante muito tempo foi o apoio à segurança do palácio. Foram residir ali, e ali instalaram seu colégio. Era apenas para os filhos do conde D'Eu e da princesa Isabel, e talvez outros membros da família imperial. Eles estavam inseridos na alta sociedade brasileira. Acho que só na República desligaram-se, porque ninguém ia deixar uma situação assim tão prazerosa como a que tinham.

Todos da família Lutz eram de grande cultura. Quando ingressei no Colégio Lutz, em 1928, tinha sete anos de idade. O colégio já era na Tijuca, na rua Otto de Alencar, 31. Já foi demolido o prédio. Entrando na rua Otto de Alencar, vindo da General Canabarro, era do lado direito. Tinha uma casa de esquina, depois duas casas geminadas, em seguida o Colégio Lutz.

Antes localizava-se na rua Mariz e Barros, quase em frente à rua Afonso Penna. Deve ter mudado de lá nos anos 1920. Ao lado do asilo Isabel, ficava o Colégio Lutz, depois uma vila e uma chácara muito grande, que era do Guilherme William Lutz. Tio Willi, nós o chamávamos. Ele ia ao colégio toda semana. Era dono da cervejaria Polônia, na rua São Francisco Xavier, onde existe hoje uma rua que vai dar na rua Dulce. A cervejaria foi inaugurada por volta de 1920. Fecharamna provavelmente quando ele morreu. Eu já a conheci funcionando. Produzia cerveja e guaraná, e abastecia o Colégio Lutz deste refrigerante. Os alunos só tomavam guaraná do tio Willi, que uma carroça ia entregar, periodicamente. A Cerveja Polônia, de tipo alemã, era muito consumida em algumas cervejarias da cidade. Na época, só havia aqui a produção da Brahma, da Antárctica e da Hanseática, que depois foi absorvida pela Brahma, na rua José Higino. Existiam outras cervejas. A Princesa já existia. Havia uma grande casa de cervejas na praça Onze, na rua Visconde de Itaúna, atual Presidente Vargas, do lado direito de quem vinha da cidade. Lá, por exemplo, se consumia a Polônia.

Eu morava na rua Morais e Silva, quase esquina com Otto de Alencar. Fui para o colégio porque minhas irmãs já estudavam nele. E esse colégio preparava para a vida. Ensinavam à criança francês, inglês e alemão. Fui alfabetizado em alemão por dona Matilde, segunda 
“esse colégio preparava para a vida. Ensinavam à criança francês, inglês e alemão. Fui alfabetizado em alemão por dona Matilde, segunda irmã de Adolpho Lutz." irmã de Adolpho Lutz. Era uma senhora baixa, já idosa, de uns 82 anos. Hoje estou com a idade dela, 81 anos. Enxergava mal e por isso usava uma lente. Para ler uma letra da cartilha, usava óculos e ainda essa lente de aumento manual. Tudo ela olhava com a lente. E ensinava cantando. O abecedário também. Depois, algumas músicas, e tomava a lição sempre em alemão. Eu tinha seis anos.

Se ela era austera? Não. Austera era a sobrinha dela, Paula Elisabeth Warnstorff. O colégio era inicialmente da Matilde, depois ficou com a Paula e a Gertrudes - dona Paula e dona Gertrudes, nos as chamávamos. ${ }^{2}$ Essas eram duas alemãs perfeitas. Só se comunicavam em alemão, não obstante ensinassem também francês e inglês. Eram filhas de Maria Elisabeth, ou dona Isabel, irmã de dona Matilde. A Gertrudes tinha como se fosse um pequeno bócio no pescoço. Era aloirada, cabelo arrumado em coque. Devia ter sido uma moça muito bonita. As duas morreram solteiras, dona Gertrudes antes de dona Paula.

No tempo em que eu estudei no Colégio Lutz, a Matilde, irmã da Isabel, do Adolpho Lutz e do William Robert Lutz, era a chefe do clã. Tinham um irmão mais moço, que era engenheiro civil, Arnaldo Lutz, formado aqui na Escola Politécnica. Mas ele ficou doente. Já o conheci com a doença mental. Chegávamos no colégio - a entrada era às dez horas - e os quadros-negros já estavam repletos de poesias escritas pelo Arnaldo, com uma letra bonita, bem torneada, constante, todas em alemão.

As aulas eram de dez ao meio-dia, depois de uma às quatro. Na mesma sala, estudavam alunos de seis anos, como eu, e moças de vinte. Todos moravam ali perto. Tenho colegas que estudaram lá comigo, engenheiros hoje, que foram preparados para entrar na escola de engenharia, menos na parte de matemática.

Dona Matilde ensinou-me as primeiras letras, ensaiando música e tudo. Dona Paula e dona Gertrudes ensinavam matemática. Eu fazia caligrafia e leitura com a dona Paula também. Foi ela que me ensinou a ler. Desenhávamos quadrinhos e pauzinhos no caderno para melhorar a caligrafia. Dona Paula era alta. Devia ter cinqüenta e poucos anos por volta de 1927. Ensinava português, francês, inglês e alemão. Falava italiano. Todas eram professoras natas!

Aprofundavam literatura brasileira, francesa e alemã. Davam geografia, história, a chamada história universal, e corografia do Brasil. Fazia parte do aprendizado a mitologia grega e romana, todos os deuses gregos e romanos, um diletantismo característico da época. O curso de mitologia era intenso.

Em termos de idéias políticas, eram liberais, mas tinham uma tradição de defesa da hegemonia alemã. Era ostensivo. Usávamos um livro francês de história que fazia críticas à Alemanha num dos capítulos sobre o cerco de Paris. Elas não arrancaram as folhas, mas pintaram

\footnotetext{
${ }^{2}$ Paula Elisabeth, nascida em 1875, e Gertrudes, nascida em 1880.
} 


“A Bertha Lutz ia
sempre ao
colégio para
contar histórias
... Era uma típica
moça alemã.”

de preto, com tinta de sapato, todos os parágrafos que se referiam à hegemonia francesa. A hegemonia era alemã. Agora, falavam francês muito bem. Inglês também. Dona Matilde falava português bem, mas com sotaque de alemã. Já dona Isabel, a mãe da Paula, não. Ela era muito surda. Usava um megafone como aqueles que se vêem em filmes antigos, pendurado no pescoço. Encostava-o no ouvido e viravao para o interlocutor.

Ensinavam matemática, mas somente até a aritmética comercial, não entravam na álgebra. Davam muita ênfase à regra de três, aos juros e juros compostos, entravam também em raiz quadrada e cúbica e geometria. Não entravam na álgebra. Só fui ver álgebra quando estudava no Colégio São José. Minhas irmãs nunca tinham visto logaritmo. Agora, a parte de aritmética era completa. Lecionavam ainda desenho e, de três às quatro horas da tarde, costura. As meninas tinham essa aula, e os meninos ficavam apenas sentados na sala eram trinta carteiras - , para assistir dona Gertrudes, uma admirável contadora de histórias. Eu com seis, sete anos, por exemplo, já conhecia o Conde de Monte Cristo. Ela contava com perfeição, sem ler, tudo de memória, e parava às quatro horas. Parava e dizia: "Amanhã nós vamos abordar tal aspecto." Numa seqüência, como se fosse um filme! Era uma senhora contadora! Ouvi embevecido Conde de Monte Cristo, Miguel Strogoff, o mensageiro do czar, a história da Revolução Francesa. Eu tinha a impressão de que estava vendo a luta, a tomada da Bastilha. Todo dia, de segunda a sábado, nessa hora ela contava... As meninas bordavam e ouviam. Eu tinha de fazer um desenho para melhorar a habilidade manual.

A Bertha Lutz ia sempre ao colégio para contar histórias, também. Ia ajudar dona Paula e dona Gertrudes a cuidar daqueles meninos. Porque elas tinham que lecionar para os alunos mais velhos e ocupar os menores com assuntos de instrução, o que era feito, em parte, por dona Matilde, mas a Bertha Lutz também fazia muito isso. Era uma típica moça alemã. Usava um cabelo cortado, rente assim, com uma franjinha. Bertha Lutz era a cara de um cientista. Se era boa contadora de histórias? Era admirável, tão boa! Mais tarde, já em 1953, fui morar ao lado de sua casa, na Estrada Velha da Tijuca, 212. Conversava com ela. Ela era uma mulher admirável, mas diziam que tinha um gênio muito difícil. Vivia com grandes cães bravos dos quais nunca se separava.

Não tive uma avaliação da inteligência do Willi Lutz. Ele estava sempre rindo. Parecia viver alegre. Tinham uma biblioteca boa em casa, num salão: nesta biblioteca parecia morar a história dos Lutz. Nas paredes, cartazes classificavam as raças, retratando-as nos cinco continentes.

Era uma turma só. Não havia classes separadas nem séries. As alunas eram levadas para uma sala ao lado, quando, por exemplo, iam estudar inglês. Dona Gertrudes e dona Paula separavam cinco, seis 


“A festa máxima
do colégio era o
aniversário de
dona Paula e
dona Gertrudes
... vinha o tio
Willi ... Era um
homem
sorridente, um
autêntico
cervejeiro. O
oposto do
Adolpho Lutz.”

alunos, e se isolavam. Alguns desciam para a dona Matilde. No meu tempo, elas eram preceptoras! Davam até curso de boas maneiras.

Se davam aula juntas? Não. Uma de cada vez. O Arnaldo Lutz chegou a dar aulas.

A escola tinha um terreno amplo no centro do qual se erguia a casa bem grande, eu diria que de estilo nórdico, com madeiras aparentes, inclusive nas sacadas. Uma escadaria dominava a fachada. Era uma chácara, com um quintal de uns setenta metros de profundidade. No segundo pavimento funcionava o colégio, no terceiro residia dona Isabel, as duas filhas, dona Matilde, o Arnaldo e mais uma moça, Lúcia, filha de um empregado, que foi criada como filha por dona Paula. Tinha sido aluna dela, a Lúcia, que casou com um alemão, Eugênio.

Vocês perguntam se era muito rígida a disciplina? Dona Paula era. O primeiro pito feio que levei foi dela. Cheguei no colégio e, enquanto esperava, abri o armário do gás. Levei um pito da dona Paula como se tivesse cometido um crime. Aquilo me desestruturou. Já a dona Gertrudes, não, tudo ela passava a mão. Dona Paula era a austeridade em pessoa. Uma alemã velha cozinhava com a ajuda de uma senhora negra, empregada deles, a Benedita.

Eles eram muito ligados. As grandes datas do colégio eram ou o aniversário de dona Paula, ou o aniversário de dona Gertrudes. Toda semana a família ia visitar dona Isabel e dona Matilde. Eram tratadas com muito respeito. O próprio Adolpho Lutz ia visitá-las.

A festa máxima do colégio era o aniversário de dona Paula e dona Gertrudes, ao qual comparecia toda a familia. Os alunos eram solicitados a fazer uma subscrição para comprar um presente. Então, era praxe cada um dar cinco mil-réis. No dia do aniversário, às quatro horas da tarde, a homenageada recebia os alunos para um chá. Naquele dia não havia aulas. Nesse chá, na sala de visitas, vi o Adolpho Lutz. Vinha também o tio Willi. Era muito amigo delas. Extrovertido, aberto, ria muito. Era um homem sorridente, um autêntico cervejeiro. O oposto do Adolpho Lutz, cujo retrato espelha bem sua personalidade. Era um homem discreto, alto, usava óculos com as lentes redondinhas, e uma barbicha. Já o conheci com uns setenta anos, um pouco alquebrado. Vigoroso era o Willi. Morava na rua Mariz e Barros, onde é hoje o Senai. Tinha uma condição de vida boa, porque morava num palacete! Sua mulher, Maria Francisca Marinho, faleceu em 1903, de tuberculose, parece. Em 1942, quando visitei a Noroeste do Brasil, conheci um de seus filhos, o Américo Marinho Lutz, engenheiro ferroviário e diretor da ferrovia.

Então, às quatro horas, quando começava o chá, entrávamos com o presente. A mesa estava pronta, a família toda lá. Mesmo depois de mudar de colégio, continuei a freqüentar essas festas, porque tinha uns doces alemães admiráveis, o chocolate quentíssimo, muito bom. E a surpresa das duas era sempre a mesma: "Ah, não...!" Essa era uma característica, a surpresa das duas professoras com a manifestação dos 
“O Gualter não era parecido com o pai, fisicamente. Era um homem forte, atarracado, não muito alto ... Calado, mas muito simpático. Foi casado com a engenheira, Carmem Portinho.” alunos, que todo ano se repetia. Muitos ex-alunos iam. O Ilmar, já falecido, professor da Escola Politécnica; o Alberto Lélio Moreira, que está com 86 anos, lúcido, perfeito! Quem mais? As filhas do Faria Pinto, que residiam numa casa no Bulevar 28 de Setembro: Lúcia, Francisca, que chamávamos de Chiquita, e Zilda. Lembro-me ainda de Alice, e de Anita Moutinho, que morava em frente ao colégio; José Matos de Oliveira Santos; Ernesto e a irmã, Leoni Amaral; Zaíra; Maria do Rosário Barbosa, a Rosarinha; Odete; Olga; os irmãos Cleominis e Cleontes (os outros seis irmãos tinham nomes assim, começando com 'cleo'); e ainda Cecília Soares de Carvalho Couto, que ainda está viva. No Colégio Lutz estudavam também minhas irmãs Maria Elisa, Maria Celeste e Maria de Lourdes, e minha prima, Carlota Barroso de Brito.

Essa foi a vida do colégio, que deve ter acabado no final dos anos 1930. A Gertrudes ficou algum tempo doente, deixou de lecionar. Tanto que meu irmão, que era estudante de medicina, ia aplicar injeção nela. A Lúcia casou e foi para São Paulo. Dona Paula, então, vendeu o prédio e foi morar com ela. Morreu lá em 1949.

Depois que saí do Colégio Lutz fui para o São José. Em 1930, a cervejaria Polônia já era uma casa de cômodos grande.

Eu tinha 13 anos quando conheci melhor Gualter Lutz, o filho de Adolpho Lutz que foi catedrático de medicina legal na Faculdade de Medicina. Ele trabalhava naquela pesquisa sobre o câncer que o Miguel Osório de Almeida fazia no Hospital Gaffrée e Guinle. Consistia em tratar a doença com bomba de oxigênio. Introduzia-se o paciente numa cápsula, e ele ficava ali uma ou duas horas, numa atmosfera impregnada de oxigênio, que era filtrado para evitar intoxicação por carbono. Três médicos faziam parte da equipe chefiada pelo Miguel Osório de Almeida, o Gualter, o Maurício Ielpo, que já deve ter falecido, e o Mário Goullart. Toda semana meu pai, José de Barros Ramalho Ortigão, fazia essa aplicação. Fez o tratamento de 1933 até falecer, em 1935.

O Gualter não era parecido com o pai, fisicamente. Era um homem forte, atarracado, não muito alto, mais ou menos $1,70 \mathrm{~m}$. Calado, mas muito simpático. Foi casado com a engenheira Carmem Portinho. Ele tirou o primeiro prêmio na escola de medicina, e ela primeiro lugar na escola de engenharia. Ganharam uma viagem à Europa, e nessa viagem se conheceram. Gualter e Carmem Portinho separaram-se muito cedo. Quando eu o conheci, já era separado. A última vez que estivemos com ela, já estava com 96 anos. Foi quando recebeu um prêmio em Manaus, nos anos 1990. Morreu dois anos depois. A Carmem e a Bertha eram muito amigas; trabalhavam juntas no movimento feminista. Depois que se separou do Gualter, a Carmem Portinho se ligou a um arquiteto conhecido, Affonso Eduardo Reidy, que projetou o minhocão da Gávea e o Museu de Arte Moderna, de que ela foi diretora. Era um segredo absoluto. Quando ele era vivo, ninguém tocava no assunto. Moravam em Jacarepaguá. 